\title{
Workshop
}

\section{Consumer Horticulture Outreach: Communication Challenges and Solutions}

\author{
Ellen M. Bauske ${ }^{1,7}$, Gary R. Bachman ${ }^{2}$, Lucy Bradley ${ }^{3}$, \\ Karen Jeannette ${ }^{4}$, Alison Stoven O'Connor ${ }^{5}$, and \\ Pamela J. Bennett ${ }^{6}$
}

AdDitional INDEX WORDs. continuing education, extension, Master Gardener, social media, volunteer

\begin{abstract}
SUMMARY. Communication is a critical issue for consumer horticulture specialists and extension agents. They must communicate effectively with the public interested in gardening, with Extension Master Gardener (EMG) volunteers and with other scientists. A workshop was held at the Annual Conference of the American Society for Horticultural Science on 22 July 2013 in Palm Desert, CA, with the intent of sharing tips and techniques that facilitated consumer horticulture and EMG programming. Presentations focused on communication. One program leader reported on the North Carolina Master Gardener web site, which integrates an online volunteer management system (VMS) with widely available web tools to create one-stop shopping for people who want to volunteer, get help from volunteers, or support volunteers at both the county and state level. Another program used the state VMS to house videos providing continuing education (CE) training required for EMG volunteers. This training is available 24 hours per day and 7 days per week. Agents created the videos by recording live presentations with widely available, screen capture software and a microphone. Features that make the social media site Pinterest a strong tool for gathering together focused programming resources and professional collaboration were outlined. Finally, the use of a compact, subirrigated gardening system that uses peat-based potting mix was suggested as a means to simplify communication with new urban gardeners and address their unique gardening issues.
\end{abstract}

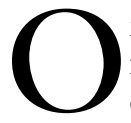
ne of the greatest challenges for consumer horticulture specialists and extension agents is communicating effectively with their broad audiences. Even when narrowed to home and community food gardening, the target audience is immense. In 2008, $31 \%$ of all U.S. households, an estimated 36 million households, participated in food gardening (National Gardening Association, 2009) and this number increases annually (Butterfield, 2013). Moreover, the demographics of this group encompass a broad cross section of the U.S. population and include all ages, education levels, income levels, martial statuses, household sizes, genders, and regional locations.

Consumer horticulture extension specialists and agents are asked to address many issues. Gardeners have unique interests in plant material and gardening techniques, as well as varying levels of interest in organic, sustainable, and traditional practices. In addition, today's gardeners and scientists are often interested in ecological services that gardens may provide. These services can include conserving biodiversity, protecting water resources, improving microclimate, and sequestering carbon (Lovell and Taylor, 2013). Some expectations fall well outside the typical purview of horticulture. As Lovell and Taylor (2013) noted, community gardens may play an important role in helping participants organize, serving as sites for political mobilization and resistance to marginalization.

Perhaps the most successful and well-known outreach initiative in consumer horticulture is the EMG volunteer program. Initiated in 1972, the program trains EMG volunteers to provide research-based gardening information to the public (Meyer, 2007). The program has spread to all 50 states, the District of Columbia, and 4 Canadian provinces (National Master Gardener Committee, 2013). According to the last Cooperative State Research, Education and Extension Service (2009) report, there were $\approx 95,000$ active volunteers in the United States and Canada. Instructors are generally Cooperative Extension agents or specialists at land-grant universities. The contribution of EMG volunteers to extension programs is well documented (Martin, 2009).

Communication issues within the EMG program can be daunting. Often a single coordinator oversees the program statewide, with county or regional agents (or coordinators) overseeing volunteers on a local scale. Statewide EMG programs can have thousands of participants interacting with the public who request services and information about the program.

Extension specialists, agents, and volunteers compete to be heard by their clients and prospective clients over commercial and other entities. Internet searches yield a plethora of information from national chain stores, local stores, nurseries, blogs, etc. Eccentric information and sales pitches are as readily available as researchbased information. Clientele may be confused by conflicting information.

The use of social media has proven effective for many communicators, but can be challenging for extension professionals. Extension professionals rarely have the time, experience, or professional support to pull together thoughtful social media campaigns and their "product" 
is complex, research-based gardening information that changes seasonally and with external events (e.g., weather patterns, pest outbreaks, and trends).

\section{Materials and methods}

The workshop was held at the Annual Conference of the American Society for Horticultural Science on 22 July 2013 in Palm Desert, CA (Bennett, 2013) and $\approx 20$ people attended it. The intent was to share tips and techniques that facilitated consumer horticulture and extension Master Gardening programming. These tips were presented in "lightening round format" with 5- to 7-min presentations. This workshop included four presentations highlighting projects and tools that increase program outreach in consumer horticulture.

\section{Results and discussion}

The intent of this workshop was to discuss ideas to increase the impact of consumer horticulture programming. Interestingly, all the discussion and presentation focused on communication issues.

Managing InTERnet EMG COMMUNICATION WITH THE PUBLIC, VOLUNTEERS, AND SUPPORTERS. Cooperative Extension is a bottom-up system. Each county offers unique programs and organizes their web sites and local information differently. As a result, when the public seeks information about the EMG program, calls often come to the state coordinator, rather than the particular county extension office that will provide service. Statewide EMG web

This paper was part of the workshop "Ten Great Ideas for Your Master Gardener/Consumer Horticulture Program" held 22 July 2013 at the ASHS Conference, Palm Desert, CA, and sponsored by the Consumer Horticulture/Master Gardener Working Group.

We thank the participants in this workshop for their contribution to this work.

${ }^{1}$ Center for Urban Agriculture, University of Georgia, 1109 Experiment St., Griffin, GA 30223

${ }^{2}$ Coastal Research and Extension Center, Mississippi State University, 1815 Popps Ferry Road, Biloxi, MS 39532

${ }^{3}$ Department of Horticultural Science, 128 Kilgore Hall, Box 7609, North Carolina State University, Raleigh, NC 27695

${ }^{4}$ eXtension, 1838 Vermilion Road, Duluth, MN 55803

${ }^{5}$ Colorado State University Extension, 1525 Blue Spruce Drive, Fort Collins, CO 80524

${ }^{6}$ Ohio State University Extension, 4400 Gateway Blvd., Suite 104, Springfield, OH 45502

${ }^{7}$ Corresponding author. E-mail: ebauske@uga.edu. sites often provide an overview of the entire program with little information about county resources, activities, and programs. A potential EMG volunteer or someone seeking services may have little information about options available in their area.

The ideal web site would provide statewide as well as county-specific information, essentially one-stop shopping for people who want to volunteer, get help from volunteers, or support volunteers. It would also display county and statewide information on EMG activities and impacts, sharing this information with the public and dynamically demonstrating the value of the program.

The North Carolina EMG program has addressed these challenges by integrating their existing online VMS with widely available web tools. The statewide EMG web page displays real-time numbers of volunteers, hours volunteered, and in-kind donations, in addition to last year's totals (North Carolina Cooperative Extension, 2014). Success stories are pulled from impacts submitted online to the annual faculty evaluation report system. A rich site summary (RSS feed) searches for and delivers news articles that feature the terms "Master Gardener" and "North Carolina." It includes a live feed from the North Carolina EMG Facebook page (Facebook, Menlo Park, CA). A widget (small application executed on the web page) for viewing the eXtension National EMG blog (eXtension, 2014) is also included. These features ensure a constantly updating and interesting statewide page.

County-specific public EMG web sites can be edited through the VMS and can be managed by county agents. Agents can also designate volunteers or staff to manage the site, easily delegating these web tasks. Real-time numbers for county volunteers, including hours volunteered and in-kind donations are displayed on each county site. County administrators can add county-specific information on becoming, supporting, or getting help from EMG volunteers. County blogs, Facebook pages, hours of operation, emails, agent information, and any relevant content can be included.

A shared, public, searchable Google calendar (Google, Mountain
View, CA) has the capability to display local events by location, topic, or date. Both state and county web sites display a prominent "Support the Volunteers" option, which reflects state program needs on the state page and local needs on the county pages.

Though some of what is discussed herein is unique to the North Carolina EMG web site, three components have broad applicability. This integrated, statewide EMG portal relies heavily on widely available widgets and reduces the need for constant updating. Agents can delegate maintenance and updating of web sites to volunteers or staff, reducing their workload. Finally, the system makes full use of volunteer statistics gathered by the VMS, creating an impressive display of the value of the EMG program to the state and county.

CONTINUING EDUCATION FOR EXTENSION MASTER GARDENERS. COlorado State University requires that EMG volunteers complete $24 \mathrm{~h}$ of volunteer time and $12 \mathrm{~h}$ of CE, $6 \mathrm{~h}$ of which must be provided by Colorado State University. Providing educational opportunities for $\approx 1800 \mathrm{vol}$ unteers in 29 Colorado counties is a substantial task. An internal survey of agents initiated in 2011 (D. Whiting, personal communication) identified three counties that did not provide any $\mathrm{CE}$ opportunities for volunteers. Five other counties offered only a few hours. Even so, agents estimated they spent a total of 242 d per year statewide providing training opportunities. In addition, many EMG volunteers expressed concerns that $\mathrm{CE}$ offerings were not convenient to their schedules or home/work places, topics were often repeated, and CE classes with fees for supplies or speakers were costly.

One solution to these challenges is to provide $\mathrm{CE}$ in an asynchronous, online format, thus making CE training available to all EMG volunteers $24 \mathrm{~h}$ per day and $7 \mathrm{~d}$ per week. At Colorado State University, agents created video training and presentations by screen capture. Software is available, which allows a live presentation to be recorded, capturing the enthusiasm generated by the audience and speaker interaction. The speaker's PowerPoint (MicroSoft Corp., Redmond, WA) presentation is easily captured and the vocals are recorded with a microphone using software such as Camtasia Studio 
(TechSmith Corp., Okemos, MI). The recorded presentation can be edited, modifying both audio and video tracks. Sound effects, pictures, music, video, and voice overlay can be added to emphasize or explain content.

The CE trainings are offered via the VMS used by the Colorado State University EMG program. Fourteen topics are currently available with over $35 \mathrm{~h}$ of instruction and over 20 $\mathrm{CE}$ training sessions are in the editing process. Most of the classes are broken up into short learning segments (10 to $20 \mathrm{~min}$ ) that are conducive for most adult learners (Vai and Sosulski, 2011). Training sessions can be paused and stopped as necessary to accommodate the needs of the learner. Most training sessions include a laboratory that the learner can do with simple household products or by observing things in their own landscape and gardens. The VMS is password protected, providing exclusivity to the volunteers. Some volunteers see access to these videos as yet another benefit of the EMG program.

In 2013,135 volunteers received $476 \mathrm{~h}$ of online CE in the pilot of this program. Volunteers report that they miss the social interaction of a group class. However, in some counties, volunteers gathered together to watch the $\mathrm{CE}$ training videos. This technique has been used successfully with other distance learning technologies (Bauske et al., 2009).

PIN IT! The Internet has become an integral part of extension outreach and offers both opportunities and challenges to reaching target audiences. The social media site Pinterest (Pinterest, San Francisco, CA) has gained momentum as a way to share content and is growing faster than any other social media service (Hof, 2014). In 2013, Pinterest growth (58\%) outpaced Facebook's (57\%) and Twitter's (Twitter, San Francisco, CA) growth (15\%).

Pinterest is an online service that allows users to create "pin boards" (themed picture collections) that visually bookmark web sites and manage these bookmarks. Most often Pinterest "pins" are pictures taken from the web site they bookmark. Users can retrieve or share boards with others. Users can browse other pin boards and "re-pin" images to their own pin boards or "like" photos. Gardens, vegetables, landscape design, container ideas, and ornamental plants are visually appealing, making ideal pins for Pinterest boards.

Pinterest has features that can make it a strong tool for gathering focused programming resources together. Each pin or picture links to the original source and therefore maintains the credibility of that source. In addition, the pin can be customized with descriptions and comments, adding context. Pinterest allows the selection of an appropriate embedded image from the web site to present the content. The result can be an attractive, easy-to-use collection of research-based information for clients to discover and use.

Boards can be made for any number of topics for specific target audiences. University of Illinois Extension (n.d.) has created a Pinterest board on gardening that boasts 18,296 followers. Other boards are more focused. Northwest Illinois Extension (Miller, n.d.) has created a series of boards on topics ranging from fall gardening to gardening with pallets.

The impact of program or theme boards can be tracked by noting the number of followers, re-pins, and likes. It is also possible to use Google analytics to measure Pinterest referral traffic on existing web pages.

Pinterest offers interesting opportunities for professional collaboration. Board owners can give others permission to share and pin to their board. For example, on a shared community garden board, a poultry scientist could pin a web site about backyard chickens and a food scientist could pin a web site on food safety when harvesting vegetables. No intermediary (web master) is necessary to create a meaningful collaborative product.

SIMPLIFYING GARDENING WITH SUBIRRIGATED CONTAINERS. Specialists, agents, and EMG volunteers seek to present simple, successful solutions to the challenges beginning gardeners face, encouraging them to garden. Professionals and volunteers are well aware of the complexities and idiosyncrasies of local conditions, pest problems, soil fertility, plant varieties, and other factors that impact a garden. This is reflected in the dizzying array of comprehensive university web sites and extension publications. These sites, publications, and recommendations can be overwhelming to beginning gardeners and may not address their real concerns.

Non-gardeners often identify time, space, and knowledge constraints to gardening. (Beytes, 2013). Many work outside the home and are intimidated by perceived labor and time requirements. They may live in urban settings and require gardens with a small footprint. Some live in condominiums or apartments and would like to garden, but have a porch or balcony as the only viable available space. Renters may be unwilling to invest in soil improvement.

Suggesting the use of a subirrigated container gardening system, (e.g., EarthBox, Scranton, PA) addresses their time and space concerns. Compact subirrigated gardening systems that use peat-based potting mix work well in small urban environments.

Initially developed for commercial vegetable production (Geraldson and Whisenant, 1995) subirrigated container systems often included plastic mulch, a wicking chamber, and an overflow. These systems ameliorate watering challenges inexperienced gardeners encounter. Many systems are portable and can be moved inside in cold events.

Simplifying gardening by using subirrigated gardening systems reduces the communication needed for a new gardener to be successful. These systems reduce the need for soil testing, interpretation of soil test results, and addition of soil amendments beyond normal fertilization. Subirrigated systems can reduce the occurrence of soil-borne diseases and provide a more consistent root zone environment, which many inexperienced gardeners do not understand and frequently neglect.

Subirrigated systems provide the educator with many opportunities, particularly as their users expand food output by growing as many as three, sequential, seasonal crops. This gives extension educators the opportunity to introduce additional topics such as cultivar selection, soil fertility, $\mathrm{pH}$, and integrated pest management.

\section{Conclusions}

All of these projects create solutions to challenges articulated by the public, EMG volunteers, agents, and specialists. At a minimum, the ideas presented in this workshop may help 
consumer horticulture extension professionals increase outreach, target audiences, and save time as they struggle to communicate with their wide audiences. In a broader sense, the workshop presentations underscore many of the challenges scientists face when communicating with the public.

Public communication is undergoing a structural transformation caused by online communication (Nielsen, 2012). It is not yet fully clear how science will transfer to the Internet. Some expect science journalism to transfer successfully, resulting in online versions with interactivity, hypertext structure, and multimedia (Peters, 2013). Others see a brave new world of social media, bloggers, and citizen science journalists.

It is clear that extension education must meet the needs of a growing constituency that not only desires, but expects to find all forms of education and information online (Diem et al., 2011). One challenge for specialists and agents is to maintain scientific standards while relinquishing some control and allowing other people, or widgets, to create and provide content. As illustrated by presentations reported herein, careful selection of widgets and sources is critical.

Consumer horticulture professionals are fully engaged in "direct, face-to-face and dialogic communication between scientists and members of the public," (Peters 2013). Scientists and the public have different communication expectations and needs. Fischhoff (2013) noted that a science education begins by listening to scientists and learning the facts that they wish to convey. In contrast, communicating science with the public starts by listening to the audience, identifying the decisions they face, and then supplying the information they need, allowing them to make informed decisions. When a scientist answers the question, "how can I start a vegetable garden?" the answer may contain far more information than a layperson expects and may address none of their concerns. The simple answer, "use a sub-irrigated gardening system," addresses many of the space and time constraints new gardeners identify, as well as the knowledge constraints they may be unaware of.

\section{Literature cited}

Bauske, E.M., F.P. Henning, and M.T. Fonseca. 2009. Southeast Master Gardeners trained to tackle watershed issues using cost-effective distance teaching technology. 20 Dec. 2013. <http:// www.gwri.gatech.edu/sites/default/ files/files/docs/2009/3.3.1_Bauske.pdf>.

Bennett, P.J. 2013. Ten great ideas for your Master Gardener/consumer horticulture program. HortScience 48:S82. (abstr.).

Beytes, C. 2013. A college class asks: Why don't people garden? 30 Jan. 2014. <http://www.ballpublishing.com/ growertalks /ViewArticle.aspx?articleid= 20101>.

Butterfield, B. 2013. New 2013 national gardening survey. 15 Jan. 2014. <http:// www.garden.org/articles/articles.php?q= show\&id $=3737>$.

Cooperative State Research, Education and Extension Service. 2009. 2009 Extension Master Gardener survey. 11 Nov. 2013. <http://www.extension.org/ mediawiki/files/f/f5/Extension_MG_ Survey_4-9.pdf $>$.

Diem, K.G., J. Hino, D. Martin, and T. Meisenbach. 2011. Is extension ready to adopt technology for delivering programs and reaching new audiences? J. Ext. 49(6):6FEAl. 4 Jan. 2014. <http:// www.joe.org/joe/2011december/ al.php>.

eXtension. 2014. Extension Master Gardener. 29 Jan. 2014. <http://blogs. extension.org/mastergardener $/>$.

Fischhoff, B. 2013. The sciences of science communication. Proc. Natl. Acad. Sci. USA 110:14033-14039.

Geraldson, C.M. and B. Whisenant. 1995. The EarthBox - A containerized gradient concept. Proc. Florida State Hort. Soc. 108:420-421.

Hof, R. 2014. Pinners are from Peoria: Sharing on Pinterest takes off. 16 Jan.
2014. <http://www.forbes.com/sites/ roberthof/2014/01/16/pinners-are-frompeoria-sharing-on-pinterest-takes-off/> .

Lovell, S.T. and J.R. Taylor. 2013. Supplying urban ecosystem services through multifunctional green infrastructure in the United States. Landscape Ecol. 28:1447-1463.

Martin, J. 2009. USDA Master Gardeners available to help Americans grow safe, healthy food throughout the country. 10 Jan. 2011. <http://www.csrees.usda. gov/newsroom/news/2009news / 07091_master_gardener.html>.

Meyer, M.H. 2007. The Master Gardener program 1992-2005. Hort. Rev. (Am. Soc. Hort. Sci.) 33:393-420.

Miller, C. n.d. Northwest Illinois extension horticulture. 4 Apr. 2014. <http:// www.pinterest.com/nwilexthort/>.

National Gardening Association. 2009. The impact of home and community gardening in America. Scotts MiracleGro Co., Marysville, $\mathrm{OH}$.

National Master Gardener Committee. 2013. State and provincial Master Gardener programs: Extension and affiliated program listings. 2 Feb. 2013. <http://www.extension.org/pages/9925/ state-and-provincial-master-gardenerprograms:-extension-and-affiliatedprogram-listings $>$.

Nielsen, R.K. 2012. Ten years that shook the media world. 20 Jan. 2014. <https://reutersinstitute.politics.ox.ac.uk/ fileadmin/documents /Publications/ Working_Papers/Nielsen_-_Ten_Years_ that_Shook_the_Media.pdf $>$.

North Carolina Cooperative Extension. 2014. Extension Master Gardener volunteers. 4 Apr. 2014. <http://www. ncstategardening.org $/>$.

Peters, H. 2013. Gap between science and media revisited: Scientists as public communicators. Proc. Natl. Acad. Sci. USA 110:14102-14109.

University of Illinois Extension. n.d. Gardening. 4 Apr. 2014. <http://www.pinterest. com/uiextension/gardening/>.

Vai, M. and K. Sosulski. 2011. Essentials of online course design: A standards-based guide. Routledge Press, New York, NY. 